Type, long, oval face, arched nose, head mesaticephalous, that is, intermediate between the round and the long, measured horizontally, with cranial index $79 i^{1}$ fair complexion, thick beard, hair and eyes generally black, but light blue or grey eyes and brown hair common amongst the Rohillas, ${ }^{2}$ as the Suleimân highlanders are often collectively called.

The great bulk of the people are Sunnites, which is one of the causes of their profound aversion to the Persians, who are mainly of the Shiah sect. Yet the nobles and upper classes, especially amongst the Durânis, usually converse and always correspond in Persian. The consequence is that the Pukhtu, or national language, has remained a somewhat rude idiom, seldom employed in literature, and in refined society regarded as little better than a provincial patois. Its importance philologically is considerable, for though usually grouped with the Iranian branch of the Aryan family, Dr. Ernest Trumpp (Grammar, I873), gives it a more independent position as intermediate between the Iranic and Indic, while Prof. Haug, of Munich, now regards it as a separate member of the family. It is very harsh and spoken with considerable dialectic variety everywhere in Afghanistan proper except the Hazarajat, and also in the Peshâwar district of British India. The most marked dialects seem to be the Kandahari, Dir, Tirhai, Peshâwari, Khaibari, Tarni, Vazîri, and Ushtarâni. The Pashae and Laghmâni, sometimes included in the list, are not Pukhtu at all, or even Iranian, but distinctly Sanskritic, closely allied to the Siah Posh and Kohistâni.

A. H. KEANE

\section{THE METEOROLOGY OF SOUTH AUSTRALIA ${ }^{3}$}

$\mathrm{M}^{\mathrm{R}}$. CHARLES TODD sends us a well-written and Adelaide during 1878 , illustrated with a map showing the positions of the II 5 stations for the observation of the rainfall of that part of Australia and their rainfall for the year. Along with the monthly rainfall for 1878 there are printed the monthly means of forty-three of the stations at which the rainfall has been recorded for at least eight years. Since these stations extend right across the continent from Palmerston in the north to Cape Northumberland in the south, we are now, through this boldly designed system of observation, obtaining just notions of the agricultural and pastoral capabilities of the colony, in so far as these depend on that prime factor of climate, the rainfall.

The rainfall of South Australia depends, on the one hand, on the tropical rains, which extend from the north coast inland, and prevail from November to April ; and on the other hand on the winter rains, which extend from the south coast northwards into the interior, and prevail for the seven months ending with October.

The tropical rains extend in a greater or less degree across the interior, as far as lat. $26 \mathrm{~S}$., falling off very considerably, however, south of Daly Waters, in lat. $16^{\circ}$ I $5^{\prime}$. The breadth over which these rains spread southwards and their copiousness depend altogether on the strength and southerly dip of the north-west monsoon, and consequently in the years when this monsoon blows over Australia with diminished force, a large tract of territcry becomes nothing but an arid waste.

A different state of things, however, prevails along the north coast and for a few hundred miles inland. There the summer rains fail not. At Palmerston, for example, the average of the past nine years gives a monthly fall

I Barnard Davis, "Thesaurus Craniorum."

2 From roh =the Persian koh=mountain, whence also Rohilcund, in Northern India.

3 "Meteorological Observations made at Adelaide Observatory during " $876-77-78$," under the direction of Charles Todd, C.M.G.. F.R.A.S. “R.M.G., F.R.A.S. Adelaide, 1879. for each of the four months, from December to March, of 12.38 inches; in April, October, and November, the monthly mean is 3.68 inches; in May and September it is small, and in June, July, and August no rain falls. Here, then, is a large region, doubtless with a great future before it as regards the supply of the markets of the world with fruits and other tropical produce, such as have long been shipped from the rich plains of India and Ceylon.

The winter rains occasionally extend well up into the interior, sometimes passing the centre of the continent; but generally they thin off about Ioo miles north of Spencer's Gulf, and are heavy north of this gulf only along the Flinder's range of mountains. The area of minimum rainfall of the continent extends from the Great Australian Bight to the northern extremity of the Flinder's Range, over the plains to the east of this range up to latitude $25^{\circ}$, and spreads either way to within perhaps a few hundred miles of the east and west coasts.

The agricultural districts of South Australia are marked off by the method of distribution of these winter rains ; and roughly speaking, they lie for some distance northwards along and in the immediate vicinity of the Flinder's Range, and thence southwards along the coast to Cape Northumberland. This broadish strip of territory constitutes, then, the granary of the colony ; and looking at Mr. Todd's rain returns in connection with the broad physical features of the region, it is likely always to remain so.

The close connection between the average quantity of wheat reaped per acre and the rainfall is shown in a table, giving for each year beginning with 186 I the yield per acre and the monthly rainfalls deduced from the observations of rain made over the agricultural districts during these eighteen years. In 1878 the rainfall over the agricultural districts was nearly 3 inches under the average, and the yield of wheat was only 7 bushels 9 lbs., or nearly three bushels under the average. Still more instructive would the comparison be if, instead of lumping the districts together, their average rainfall and average yield of wheat were presented in a separate form.

The Meteorological Observations made at Adelaide Observatory, published monthly, show also the rainfall at all the rain stations with remarks, the appearance of which cannot but be watched with the liveliest interest by the Colonists. Thus in January, 1876 , it is noted that the monsoon scarcely reached the MacDonnell Ranges, south of which, and as far as the east coast, drought prevailed; and in the following month the information is given that although 10 inches of rain fell at Port Darwin, the monsoon rains were comparatively light and barely reached the centre of the continent.

The observations at the Adelaide Observatory are made, printed, and discussed with extremely satisfactory fulness for an observatory not furnished with continuously recording instruments. Of special value are the comparisons made of each month's observations with the means of these months from past observations. The sorting of the wind observations into the directions for each hour of observation, viz., 6 and 9 A.M., noon, 3, 6 , and 9 P.M., give most interesting results. These show for the summer months a shifting of the wind from a southeasterly direction in the morning to a south-westerly direction in the afternoon, a result doubtless due to the situation of Adelaide with reference to the heated interior of the continent, as that heating varies during the twenty-four hours.

The weak point of this system of meteorological observation is the total absence of barometrical and thermomefrical observations at all the stations except Adelaide. Such observations were made at some half dozen stations during $1861-64$, but since then we miss them from the reports. It would not be possible to exaggerate the importance, not only to the colonists themselves, but to 
the whole body of meteorologists over the globe, of the establishment of such a system of weather observation across this continent; and, moreover, the establishment of an efficient system of stations with their necessary equipment of instruments and observers, could not be in better hands than his whose resolute will and organising genius girdled Australia with the telegraph.

\section{$A L G E^{1}$}

PROF. J. G. AGARDH has taken advantage of the leisure afforded by his retirement from the Chair of Botany which he has filled so successfully for many years at the Lund University, to compose another work on algology. This very interesting volume, which embodies the results of observations made by the Professor during a long course of years, on the Morphology of the Floridex, has just appeared in the Transactions of the Scientific Academy of Stockholm. It is written in the Swedish language, and is illustrated by thirty-three coloured plates of rare and little-known algæ, and of microscopic details of many others, beautifully executed by $S$ wedish artists. It treats the subject in an exhaustive manner, as will be seen from a specification of the contents. The work is divided into three parts, each part being copiously illustrated by reference to the plates, and to descriptions of different genera and species.

Part I. treats of the general aspect and outer part of the Floridex-their development and growth; of the root and its different forms; of the stem, branches, and leaves.

Part II., treating of the structure of the Florideæ, describes the nature of the cell-membrane and of the cuticle; the contents of the cell under different conditions of development; the various layers or strata of which the thallus is composed; the connection between the different cells, and the manner in which this connection is effected; the various ways in which the cells are formed ; their different positions, and the manner in which they are grouped and united with the several strata.

Part III. describes the reproductive organs, namely, the antheridia, the sphærospores, and the capsular fruit and cystocarp, and concludes with remarks on the so-called "double fructification." This third part will doubtless attract the attention of algologists who may be desirous of knowing whether the views of the Professor, in regard to the fertilisation of the fruit in the manner recorded by MM. Bornet and Thuret, have undergone any change since the publication of the "Epicrisis" in 1876 . It will be seen from the present work, that although Dr. Agardh has made multitudes of microscopic observations on British and exotic algæ, at all periods of growth, and especially of the species which formed the subject of Bornet and Thuret's experiments, he has not materially changed his opinion. He says that the observations hitherto recorded are too few in number to determine the question, and that, as yet, he has seen nothing confirmatory of the views of the French algologists. For his reasons and remarks we must refer the reader to the work itself. It is to be regretted that Dr. Dodel-Port's very interesting observations on the fecundation of the Florider by Infusoria, of which an abstract was given in NATURE, vol. xx. p. 463 , were not published before the completion of Prof. Agardh's work.

Among the verbal descriptions and illustrations are many which are especially deserving of the attention of British algologists. Among them will be found microscopic representations of the fruit, hitherto imperfectly described and figured, of many British algæ. The cystocarpic fruit of Callithamnion cruciatum is now, it is believed, figured for the first time. Among the whole figures I "Florideernes Morphologi," af J. G. Agardh. Kongl. Svenska Vetenskaps Akademiens Handlingar, Bandet 15, No. 6 (1879).

"De Algis Novæ Zelandiæ marinis." In supplementum "Floræ Hookerianæ," scripsit J. G. Agardh. Lunds Univ., Årsskrift. Tom xiv, of algx is one of a species which, although found on our southern shores, is almost unknown to collectors. This species is Nitophyllum litteratum [Plate xxvii. Figs. I-4], which may-but very rarely - be seen in collections under the name of $N$. Hillice. From this last-mentioned species it differs in form, being more lobed, and also in the fructification. The sphærospores, instead of being scattered over the disc as in $N$. Hillice, are located between the numerous veins which mark the lower part of the frond. Minor differences are shown in the microscopic details. The capsular fruit of this species does not appear to be yet known. It therefore adds another instance to the long list of Florideæ which hitherto have been found with sphærosporic fruit only.

There is some diversity of opinion as to the place in a general system of classification of certain algæ of a red or purple colour, namely, Porphyra, Bangia, and $\mathrm{Ba}$ trachospermum. By some of the later algologists they have been placed among the Florideæ, but Prof. Agardh is of opinion that they do not belong to the red seaweeds.

There is another group of algæ, which really belongs to the Florideæ, whose position in the system still appears to be uncertain. We allude to the family, Corallinee. We remember to have noticed that it is not included in the classification of the Florideæ in the Epicrisis. We are, therefore, the more disappointed that there is no notice of this interesting group in the present work. Dr. Agardh's observations with regard to it would be most welcome. Had the present very valuable work been written either in Latin or English, it would undoubtedly have been more serviceable ; as it is, however, algologists who do not understand Swedish may learn a great deal from the carefully-executed plates. Should the work be republished, it would be desirable to add a table of contents and an index.

The "List of New Zealand Algæ" is a useful supplement to the "Flora Novæ-Zelandia" of Hooker and Harvey. It consists chiefly of species which have been brought home by Dr. Berggren. The names of Hooker and Harvey have been generally adopted; but all the species described have been re-examined by Prof. Agardb, and many of them re-named in consequence of such reexamination. The new species and varieties are about sixty in number. Descriptions are given of new species, and copious notes on such of the already known species as require this addition are appended.

M. P. M.

\section{GAS AND ELECTRICITY IN PARIS}

SINCE the Jablochkoff light was established for the first time in the Avenue de l'Opera, it may be said that there has been in Paris a regular competition between gas and electricity. The "Compagnie Parisienne d'Eclairage et de Chauffage" by gas is certainly one of the largest in existence, as it possesses every gas-work in Paris, and almost every one in the vicinity. A system of subterranean pipes and valves connects all these establishments, so that gas generated in Courcelles can be sent to any part of the city and suburbs if required. All these different works were conducted as separate establishments before the fusion which took place in 1854 , under the auspices of the then existing Imperial Government. Two of these establishments are worthy of note-La Villette, as being the largest, the site of experimental and chemical work, and Vaugirard, where the retorts are warmed by the Siemens' heat-generating process.

Each of the twenty arrondissements of Paris has its special gas office. The Company also sells gas-engines, and makes great efforts to develop the use of gas as fuel for warming and cooking in private houses and shops. The price of gas is dearer in Paris than in any other capital of Europe, and the arrangements are difficult to understand without an explanation of the French municipal institutions. 